\title{
BUZZING LiNES OF FLIGHT: A SURVEY OF My OWN PRIVATE SOUNDSCAPE
}

Henry Adam Svec

University of Waterloo, Canada ${ }^{1}$

\begin{abstract}
This audio-essay explores the relationship between soundscape recordings and property. Three field recordings of the author's family fruit farm examine the emplacement and territorialization of sound but also the means by which certain signals might dislocate the discourses of ownership; stereo recordings of the acreage have been displaced by a more connective topology, courtesy of the beehives. The accompanying essay deploys an auto-ethnographic approach to reflect upon how sound recording practice can negotiate foundational ideologies within late capitalist culture.
\end{abstract}

Keywords: soundscape, field recording, bees, capitalism, swarm

When my father decided to take out the cherry, plum, peach, and apple orchards on the farm purchased in the early 1960s by my grandfather - a Czech immigrant who first worked in Canada as a servant for an ambassador in Quebec, then in the fields of a WASP fruit farmer in Southwestern Ontario, later to find a job in a greenhouse of the government, for he was a gardener by training-I was overcome by a surge of sadness. We all knew that it had to be done, because my brothers and I had moved away, unable to return anymore in the summers to help; and the small scale of the operation had been making surplus profits difficult to achieve. (This was shortly before the paradigm of "buy local" had taken off in the region, but after the North American Free Trade Agreement had made it increasingly difficult to compete with the low prices of the big grocery chains.) It was as though all value had been extracted from the trees and none remained. Thusly the fields would simply be rented out to a neighboring farmer for cash crops, alternating corn, wheat, and soybeans.

I had grown up on this farm-had climbed, picked, pruned, and irrigated these orchards. So, when I came home to visit that summer and first saw the massive pile of broken limbs and

1 Department of Communication Arts, Waterloo. Author’s Contact: hsvec@uwaterloo.ca 
dried roots down the ridge from the road, waiting yet to be burned, set to return to mere dust, I cried. I recognized even individual trees. It occurred to me that we should almost have a funeral.

What was the source of my grief? Of course, first there was simple nostalgia, a mourning of the loss of home. The smell, look, and feel of the orchards had anchored my childhood and young adult existence. In spring, the white sweet clouds of blossom and fresh, gentle winds; in summer the crimson clusters of Bing and Black English cherries weighing down leafy branches, the rich smells of rot and life; then the motley mix of autumnal colors and rains-here the trees receding, with the return to busses and classrooms - and finally the slow, snowy cover of winter. After the bulldozers came, the foundation, the soil, remained; but the core of the environment had been the arborous organisms themselves and the finely cultivated ecosystem surrounding. I would have been less upset if the house I grew up in had been demolished.

But I can hear now, too, that the loss also had to do with the alteration of the sonic environment. For the trees were key players in a multitudinous, ongoing soundscape (Schafer 1993). There was the rustling and dynamic, open shelter of the crowded orchard, and the chatter of workers or portable radios (aluminum ladders moving and rearranging) during harvest; the car doors and families by the fruit stand, where we also sold ice cream made with our fruit; and the refuge of the irrigation pond, a leafy and calm oasis amidst the toil. There were the droning crickets, the chirpy bats, and the manic birds drawn to our canopies, as well as the ever-present and annually-evolving noisemakers that we used to repel the latter-simulacra of shotguns and even looped recordings of dying warblers, none of which ever seemed to function as designed. And cutting across it all was the soundmark of the bell on my grandmother's porch, which she rang at coffee-break time, and at lunch and supper, and which could be heard from almost any spot on the farm. ${ }^{2}$ A brassy, primordial, vibratory mechanism by which both our labor and rest were coordinated.

Nostalgia, in both visual and sonic forms, was coupled also with a more material sense of loss. These were trees planted by my grandfather, which after his passing were watched over by my father, which one day perhaps would be watched over by me, for I am the eldest son. And I wonder now to what degree my fond sense memories and experiences growing up had and have still something to do, in the back of my mind, with the affective gravity of ownership. To what degree were the sonic pleasures derived from these natural/cultural marvels-we also had raspberry bushes, and strawberries, and asparagus, and bees - products of the modern discourses of land as property, which, as Aileen Moreton-Robinson (2015) has examined, has been a central ideological component of settler-colonialism? Similarly, to what degree did and does property ground the act of listening and the desire to capture sound recordings of particular places?

In this short text and in the field recordings that accompany it, I want to use my own affective experience of returning to my family's farm, which my father has recently transformed into a wildflower and bee sanctuary after several years of cash cropping, to make recordings of the soundscape. My aim is to listen in and around the land and its inhabitants and thereby to meditate on the intertwined forces of territorialization and de-territorialization that inform and inflect for me the phonographic reception/transmission of this rural location. ${ }^{3}$ The swarm has

2 R. Murray Schafer in his book The Soundscape describes the "soundmark" as akin to a landmark, a sonic signal which can be heard by all within a community and therefore defines the place (Schafer 1993: 10).

3 My understanding of "territorialization" and "de-territorialization" are indebted to Deleuze and Guattari (1987). 
long been of interest to theorists of culture, technology, and politics (e.g. Deleuze \& Guattari 1987; Galloway \& Thacker 2013; Haraway 2016; Parikka 2008, 2010). For example, in Gilles Deleuze's and Félix Guattari's A Thousand Plateaus: Capitalism and Schizophrenia, the swarm or pack is rendered in terms of what they call "the rhizome"; such non-human models of social connectivity present a "micropolitical" or dynamic "assemblage" breaking past conventional or "molar" boundaries and barriers (Deleuze \& Guattari 1987: 232-309). Hoping to contribute to this conversation, the present work wants to think more self-reflectively and personally, however, about the affective potency of the swarm when broached in terms of the soundscape.

As Mitchell Akiyama (2010) has observed in reference to the World Soundscape Project, soundscape composition has emphasized an allegedly inviolable relationship between sound recordings and particular places. Elsewhere Akiyama (2019) has connected the aesthetics of the soundscape concept as developed by R. Murray Schaffer, looking in particular at the CBC broadcast produced by the World Soundscape Project entitled Soundscapes of Canada, to settler-colonialist ideology: "The soundscapes they included in the broadcast overwhelmingly represented the nation's settler colonial past-simpler, quieter times they seemingly wished to restore. However, created at a time when Canada's immigrant populations were exploding, when indigenous activists were making important strides toward state recognition, Soundscapes of Canada was perhaps most notable for whom and what it left out" (Akiyama: 115). Inspired by Akiyama's work, I also want then to interrogate my own relationship to the land as I seek to look, listen, and field record. This piece is largely exploratory and meditative, in the spirit of the aesthetic tradition of soundwalking that Schafer and his colleague Hildegard Westerkamp (2007) helped to build; however, I additionally hope to demonstrate that, although the history of field recording in Canada has indeed been bound by colonialist-capitalist discourses, there are additionally opportunities for various unravelling events or cross-pollinations. ${ }^{4}$

IIIIIIIIIIIIIIIIIIIIIIIIII

\section{Track 1}

\section{https://archive.org/download/buzzing-lines-of-flight/Track01.mp3}

I am standing by the ditch that runs along the highway on the northern part of the farm. There was a row of sour cherries at the top of the orchard, which we pitted and sold for pies and jam; below that, as you walked down the long, slow ridge away from Highway \#3, assorted and almost random varieties of sweet cherry, some planted by the previous owners, the Macphersons, the majority planted by my grandfather. To run through the orchard as a child, over to my grandmother's house, was to engage in processual soundscape composition-the rustling of leaves hitting our heads or, if we were being naughty, the ripping or batting of a leaf or two as we sped past. I am just as close now to the road as I would have been then, but, without the shelter of the trees and their resonance in and against the breath of summer, the traffic now dominates down \#3 Highway. The RVs and trucks are extremely loud. I am proud that my father has decided to plant clover and wildflowers here, and grateful for the bee colonies that he has helped to split and multiply now into over twenty hives scattered across the property; but the soundscape amidst the clover and wildflower fields in which I am standing, at least this close to the highway, seems to be more vulnerable than our sheltered orchards had been.

$4 \quad$ Particularly influential to my practice has been the work of Hildegaard Westerkamp (1996). 
I look for refuge as I walk back towards what used to be the irrigation pond. When the orchards were taken out, the weeping willows, mulberries, and pear trees that surrounded this human-made body of water were also razed. It had been like an oasis: an old fruit stand in the corner that my grandfather had converted into a bee hive; rope swing on the far end with which we could jump into the water on the hottest days; a dock in the middle from which we caught mostly small bluegill fish at night after work. A fence, too, around the outside of the pond, making the place like an extra-private park amidst the semi-public workspace of the farm. Incredibly, however, willows grow quickly. The noise from the highway still feels much louder than I remember, but the rustling leaves and creaking branches of the weeping willows, now fully regrown, elicit the comfort of a favorite vinyl record.

On the eastern border of the property runs a strip of weeds and scrubby trees, a sort of miniature windbreak or buffer between our land and the neighbor's, across which a field of soybeans presently grows. There was a story about a previous owner of that farm, who one early spring day was witnessed by my grandfather on our land, digging up topsoil to spread back on his own fields. My grandfather was furious. The windbreak had thus not been strong enough to keep out human intruders, but neither is the pair of Rode NT5 condenser microphones that I am using to record as I stand atop weeds mere inches away from the property line. A bird flitters away out of the sanctuary near the pond and I can still trace its chirping as it moves out and away.

The western boundary is more fortified. Within the past year my dad has installed a wire fence along the entire edge on that side, from our house all the way through to the back of the bush, which comprises a quarter of the territory. I wonder whether the fence has played a role in the migratory patterns of certain wildlife, such as the coyotes and deer that pass through the area. My recording device, a MixPre-3, will not inscribe the sound of this wire fence, however, which does not seem to make a noticeable impact on the movement of the wind or birds at least. Even when I place my microphones directly in front of the wire, the obstruction does not register.

|IIIIIIIIIIIIIIIIIIIIIIIIII

Track 2

https://archive.org/download/buzzing-lines-of-flight/Track02.mp3

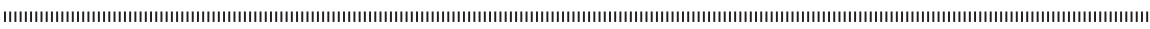

After a day of wandering around with my field recorder, harvesting, in my way, the soundscape, I follow my father as he works with his bees. He kindles paper and twigs within a small smoke-pump, which he then blows across the top of a hive, a method of temporarily stunning or subduing the creatures. We can already hear the throng of the colony. But when he removes the top lid-first cracking the seal, which the bees patiently re-glue after each time they are disturbed in this manner-there is a wild surge in amplitude. It sounds like the machinations of an industrious organism also capable of instantly modulating, in response to the slightest threat, into a defensive monster. A sprung potentiality of stingers.

I return later with my microphones to inscribe the fenced border again by the corn, then moving towards the closest hive, which sits behind a row of cedars in the bush. The corn itself, I now recognize, acts as a form of sonic boundary on the recording, a line of tight scraping and ridged swaying. Walking along this edge, the line takes on a degree of solidity in my field of audition. But as I reach the bush, ducking below branches and moving towards the hive, my 
document-in-motion is permeated by a gushing of activity and secret communication. I see the workers returning with pollen, and others leaving by the same gateway, and a cleaning crew in front on the landing of the hive. (Do bees have cleaning crews?) The overall mix comes not just from the visible members of the colony; the entire wooden structure itself seems to buzz. It might take off at any second.

Although the vocation of beekeeping feels to me part of my blood, I really know nothing about bees. But I want now to record the famous dancing itself. So, two days later my new contact mic arrives - a cheap, no-name mandolin piezo, purchased, I am ashamed to admit, through Amazon - and I am able to listen to their coordinated rhythms and energy, the totality rendered as a delicate, nimble Gestalt.

I am learning from my father that the bees pay no attention to the fences or windbreaks or ditches that enclose this broader place. They are also not competitive vis-à-vis other hives, but rather share in the bounty of pollen surrounding their routes. Through the contact mic one can thus detect a consistent, dynamic rhythm. By means of this foundation, the bees' gesticulatory and vibratory maps overflow the lines and property boundaries that for me had become almost common sense. I hear only energy and potentiality.

The bees do not attack or sting me when I check on the microphone the next day, either, though I notice that they have coated the technology with their propolis. I listen again and the soundscape is muted, softened, almost waxy. But only because we have touched one another as collaborators. It is as though they have danced directly into my ears with their excessive labour-power, their becoming-honey, their vectors. I decide to erase the other perspectival field recordings that I have made with my condenser microphones; I resolve from now on only to record, via the propolis-coated contact mic, the bees and their dancing. These are the only "field" recordings that I have included in this audio-essay.

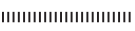

\section{Track 3}

\section{https://archive.org/download/buzzing-lines-of-flight/Track03.mp3}

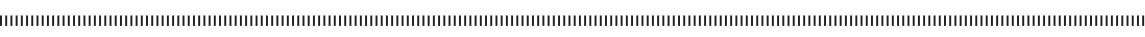

In Gilles Deleuze's and Félix Guattari's (1987) A Thousand Plateaus, the philosophers pontificate on various processes and phenomena, often drawing on the natural world for inspirations and alliances. The networked characteristics of grasses are planted in stark opposition to the sedentary and solitary characteristics of trees; considering the tree-like qualities of books and knowledge, "thought lags behind nature," they suggest (Deleuze \& Guattari 1987: 5). Another example from their text is the wasp/orchid couplet. The wasp does not simply extract pollen from the flower, but rather their meeting is a form of collaboration that provisionally dissolves the identity of both participants: "The orchid deterritorializes by forming an image, a tracing of a wasp; but the wasp reterritorializes on that image. The wasp is nevertheless deterritorialized, becoming a piece in the orchid's reproductive apparatus. But it reterritorializes the orchid by transporting its pollen. Wasp and orchid, as heterogeneous elements, form a rhizome" (Deleuze \& Guattari 1987: 10). To move from a settled state of identity-in which, for example, the wasp is a wasp and an orchid is an orchid - towards an open plain of resonance is to pursue a "line of flight," according to their playful and provocative terminology (e.g. Deleuze \& Guattari 1987: 11). 
The broad and interdisciplinary movement of post-humanist theory has followed Deleuze \& Guattari into their radical paradigm that finds logical and political fault with categorization, identity, and borders. According to science scholar Donna Haraway, for instance, the detached separation of reasonable, upright man is an illusion that props up a fantasy of domination and exploitation, against which she influentially proposes the image of the cyborg (1991: 149182). In her recent book Staying with the Trouble, Haraway proposes that the concept of the Anthropocene, which describes an historical epoch at which point the natural world has become a product too of human culture and society, is a site at which humanism persists; Haraway thus proposes instead the concept of the "Chthulucene": "The chthonic ones are not confined to a vanished past. They are a buzzing, stinging, sucking swarm now, and human beings are not in a separate compost pile" (Haraway 2016: 55).

Scholars of sound, culture, and media have long been scrutinizing the place of the senses and sound within modern and capitalist processes of subject-formation (e.g. Adorno 1990; Attali 1985; James 2019; McLuhan 2003; Ong 2002; Sterne 2003). More recent work has additionally examined the tactical utility of various sonic media as means of counter-power (e.g. Goodman 2012; Robinson 2020; Svec 2018; Weheliye 2005); the radical potential of field recording and even soundwalking have also been considered (Butler 2006; Jackson 2019; Jones \& Fairclough 2016; Paiva 2020). Informed by these discourses, as I listen back to the many field recordings I have made in and around our property lines, but also in and around the hives, and as I commune with the bees through my ears on the dance floor-and as I open up this soundscape to strangers via networked communication technologies-I can hear too the ways in which even the soundscape recording tradition is capable of undoing the stability of its own emplacement and vantage point. The registered vibrations of bees lure us into a dizzyingly busy and productive ecology, where boundaries are less significant than connections and in which the name of the game is honey, the sheer volume of which is almost always too much for any one hive alone. As Jussi Parikka has put it with respect to bee language, "Here communication becomes less a matter of abstract conveyance of symbols and more a matter of embodied interactions in intensive spatial environments" (2010: 136). Perhaps the microphone is the best way to interface with this dynamic, fruitful topology. The rich and mysterious resonance of the world when auditioned through this perspective, a map of flowing exchanges and co-responsibilities, offers an alternative diagram of bodies sounding in relation and thus also a different way of being emplaced together.

\section{BIBLIOGRAPHY}

Adorno, Theodor. 1990. "The Form of the Phonograph Record." Translated by Thomas Y. Levin. October, 55: 56-61.

Akiyama, Mitchell. 2010. “Transparent Listening: Soundscape Composition's Objects of Study.” RACAR: revue d'art canadienne/Canadian Art Review, 35(1), 54-62.

Akiyama, Mitchell. 2019. "Nothing Connects Us But Imagined Sound.” Pp. 113-129 in Sound, Media Ecology, edited by Milena Droumeva and Randolph Jordan, London: Palgrave Macmillan.

Attali, Jacques. 1985. Noise: The Political Economy of Music. Translated by Brian Massumi. Minneapolis, MN: University of Minnesota Press. 
Butler, Toby. 2006. "A Walk of Art: The Potential of Sound Walk as Practice in Cultural Geography." Social E Cultural Geography, 7(6): 889-908.

Deleuze, Gilles \& Félix Guattari. 1987. A Thousand Plateaus. Translated by Brian Massumi. Minneapolis, MN: University of Minnesota Press.

Galloway, Alexander R. \& Eugene Thacker. 2007. The Exploit: A Theory of Networks. Minneapolis, MN: University of Minnesota Press.

Goodman, Steve. 2012. Sonic Warfare: Sound, Affect, and the Ecology of Fear. Cambridge, MA: The MIT Press.

Haraway, Donna. 2016. Staying with the Trouble: Making Kin in the Chthulucene. Durham, NC: Duke University Press. Haraway, Donna. 1996. Simians, Cyborgs, and Women: The Reinvention of Nature. London, UK: Free Association Books.

Jackson, David C. 2019. "Rhythm Politics: Militant Sound Investigation, Tactical Media, and Listening to Los Angeles' Public Housing Redevelopment of Aliso Village.” Democratic Communiqué, 28(2): 14-27.

James, Robin. 2019. The Sonic Episteme: Acoustic Resonance, Neoliberalism, and Biopolitics. Durham, NC: Duke University Press.

Jones, Owain \& Louisa Fairclough. 2016. “Sounding Grief: The Severn Estuary as an Emotional Soundscape." Emotion, Space and Society, 20: 98-110.

McLuhan, Marshall. 2003. Understanding Media: The Extensions of Man. Corte Madera, CA: Ginko Press.

Moreton-Robinson, Aileen. 2015. The White Possessive: Property, Power, and Indigenous Sovereignty. Minneapolis, MN: The University of Minnesota Press.

Ong, Walter J. 2003. Orality and Literacy: The Technologizing of the Word. New York, NY: Routledge.

Paiva, Daniel. 2020. "Poetry as a Resonant Method for Multisensory Research." Emotion, Space and Society, 24: 100655.

Parikka, Jussi. 2010. Insect Media: An Archeology of Animals and Technology. Minneapolis, MN: University of Minnesota Press.

Parikka, Jussi. 2008. "Politics of Swarms: Translations between Entomology and Biopolitics." Parallax, 14(3): 112-124.

Robinson, Dylan. 2020. Hungry Listening: Resonant Theory for Indigenous Sound Studies. Minneapolis, MN: University of Minnesota Press.

Schafer, R. Murray. 1993. The Soundscape: Our Sonic Environment and the Tuning of the World. Merrimac, MA: Destiny Publishers.

Sterne, Jonathan. 2003. The Audible Past: Cultural Origins of Sound Reproduction. Durham, NC: Duke University Press.

Svec, Henry Adam. 2018. American Folk Music as Tactical Media. Amsterdam: Amsterdam University Press.

Weheliye, Alexander G. 2005. Phonographies: Grooves in Afro-Sonic Modernity. Durham, NC: Duke University Press.

Westerkamp, Hildegard. 1996. Transformations. Empreintes DIGITALes. 
Westerkamp, Hildegard. 2007. "Soundwalking." Pp. 49 in Autumn Leaves, Sound and the Environment in Artistic Practice, edited by Angus Carlyle, Paris: Double Entendre.

Date received: $2020-07-28$

Date accepted: 2021-03-03 